\title{
A formação do mestre no século XIII: um estudo sobre a sindérese e a consciência no de veritate de Tomás de Aquino
}

The teacher training in the 13td century: a study on synderesis and conscience in de veritate of Thomas Aquinas

Rafael Henrique Santin

Instituto Federal do Paraná

Terezinha Oliveira

Universidade Estadual de Maringá

Recebido em 04 de janeiro de 2018

Aprovado em 25 de setembro de 2018

Publicado em 18 de junho de 2019

\section{RESUMO}

O tema deste artigo é a proposta de Tomás de Aquino para a formação do mestre, no contexto da cristandade ocidental. Nossas reflexões, enquadradas na História da Educação e orientadas pelos pressupostos da História Social, têm o objetivo de demonstrar que Tomás de Aquino, teólogo dominicano do século XIII, concebe a formação do mestre a partir de um corpus teórico-didático que passa pelo conhecimento profundo da natureza humana e pelo compromisso com um determinado projeto de civilização. Daí a necessidade de considerarmos a relação entre ética e formação docente na obra de Tomás de Aquino. Recortamos, para este texto, as Questões 16 e 17 do De Veritate, que tratam da sindérese e da consciência. O De Veritate é um conjunto de Questões Disputadas ministradas pelo teólogo dominicano na Universidade de Paris e está, portanto, diretamente relacionada com sua atuação docente - o que, para nós, é essencial. Assim, o problema que se coloca é por que os mestres do século XIII deveriam conhecer esses elementos da ação humana.

Palavras-chave: História da Educação Medieval; Formação do mestre; Tomás de Aquino.

\section{ABSTRACT}

This article is about the proposal of Thomas Aquinas for the formation of teachers and professors, in the Occidental Christians Civilization. Ours analysis, inserted in the History of Education and founded on Social History, has an objective to demonstrate 


\section{स Wsy entuab̧a}

ISSN: 1984-6444 | http://dx.doi.org/10.5902/1984644430682

how Thomas Aquinas, Dominican theologue of the 13td century, understands the formation of teachers and professors from a corpus theoretical-educational that is focused in the profound knowledge of human nature and in the political commitment with a determined project of civilization. In this sense, is important to consider the relationship between the ethic and the teacher training on the Thomas Aquinas' work. The fonts for this article are the Questions 16 and 17 of the De Veritate, that are about the synderesis and the conscience. Thus, the problem is why the teachers and professors of the 13td century needed to know these elements of human action.

Keywords: History of Medieval Education; Formation of teachers and professors; Thomas Aquinas.

\section{Introdução}

Apresentamos, neste artigo, um estudo sobre a formação do mestre no século XIII, no contexto da cristandade ocidental, a partir da análise de uma obra de Tomás de Aquino, teólogo que manteve intensa atividade docente em paralelo com as obrigações relativas à condição de frade mendicante da Ordem dos Pregadores. $O$ objetivo principal é refletir sobre a relação entre ética e formação docente, destacando a necessidade de um projeto de civilização que dê sentido à ação educativa. Assim, observaremos que o teólogo dominicano evidencia em suas obras um compromisso com um determinado conjunto de princípios e valores que servem, também, como pressupostos teórico-práticos para a formação dos mestres no seio da Universidade medieval. Além disso, o autor submete tais princípios ao debate público, defendendo suas concepções ante seus adversários, sempre de maneira honesta e leal, e demonstrando que é possível divergir e criticar sem ofender, ser adversário sem tornar-se inimigo daqueles de quem se discorda.

As fontes que elegemos para o desenvolvimento do nosso estudo são as Questões 16 e 17 do De Veritate, intituladas $A$ sindérese e $A$ consciência. O De Veritate, conhecido no Brasil como Questões disputadas sobre a verdade, é a reunião das lições ministradas por Tomás de Aquino durante sua primeira passagem como mestre regente de teologia na Universidade de Paris, entre os anos de 1256 e 1259 o que compreende três anos letivos. A obra é constituída por 29 Questões: as sete primeiras correspondem ao primeiro ano letivo, de 1256-1257; as de número 8 a 20 foram desenvolvidas durante o segundo ano letivo, de 1257-1258; e, por fim, as de 
ISSN: 1984-6444 | http://dx.doi.org/10.5902/1984644430682

número 21 a 29 compreendem o terceiro ano letivo, de 1258-1259 (LAUAND, 2004; TORRELL, 2004). Essas lições remontam ao que Lauand (2004) chama de 'anos de maturidade' de Tomás de Aquino, tendo sido ministradas ao mesmo tempo em que o teólogo escrevia o Comentário às sentenças de Pedro Lombardo, defendia os mendicantes com o Contra impugnantes Dei cultum et religionem e se preparava para a composição da Suma Contra os Gentios. Depois de 1259, ele é enviado à Nápoles para organizar um Studim Generale dos Dominicanos naquela cidade.

A escolha das Questões 16 e 17 do De Veritate leva em consideração, ao menos, dois elementos. Primeiro, o contexto de sua elaboração e, segundo, a natureza do De Veritate. Com efeito, a segunda metade do século XIII foi marcada por intensos conflitos na Universidade medieval (OLIVEIRA, 2012). De um lado, observamos o conflito entre mestres seculares e mestres mendicantes, que procuravam garantir seus espaços nas instituições universitárias ${ }^{1}$ e, de outro, verificamos os embates entre diferentes posições acerca do homem, principalmente entre os averroístas e os teólogos adeptos de uma interpretação mais moderada das obras de Aristóteles ${ }^{2}$ - das quais o próprio Tomás de Aquino é um exemplo. Assim, as reflexões tomasianas acerca da sindérese e da consciência se inserem nesse ambiente que, para além das disputas eminentemente teóricas, se caracterizam pelo confronto de diferentes posições políticas em relação aos rumos da cristandade.

Destacamos, ainda, a natureza da fonte, isto é, a origem e as características próprias do De Veritate. Acreditamos que seja conveniente buscar as propostas de

\footnotetext{
1 Oliveira (2012) e outros historiadores que se debruçaram sobre a História das Universidades dão destaque a esse conflito, destacando-o como um dos principais episódios que marcaram o desenvolvimento dessas instituições.

${ }^{2}$ Os averroístas, dentre os quais se destacaram Siger de Brabante e Boécio de Dácia, se colocavam como interpretes legítimos das obras de Aristóteles, lidas por meio dos comentários do filósofo muçulmano Averróis. As duas principais controvérsias entre os averroístas e os leitores mais moderados giravam em torno do intelecto e da eternidade do mundo. Enquanto os primeiros concordavam com a leitura de Averróis, de que, segundo a filosofia aristotélica, é possível afirmar que os homens partilham um intelecto agente único e que o mundo sempre existiu, os segundos utilizavam as ideias do filósofo estagirita para defender que cada homem possui seu próprio intelecto agente e que o mundo teve um início e, portanto, terá um fim. Tomás de Aquino participou ativamente desses confrontos de ideias - que implicavam diferentes projetos de civilização -, posicionando-se, principalmente, por meio de duas obras: a Unidade do Intelecto Contra os Averroístas e a Suma Contra os Gentios. Entretanto, é possível encontrar reflexos desses debates em outras obras tomasianas, como a Suma Teológica.
} 
ISSN: 1984-6444 | http://dx.doi.org/10.5902/1984644430682

Tomás de Aquino para a formação do mestre no século XIII em obras que ele tenha produzido pela e para a atividade docente ${ }^{3}$. Esse é exatamente o caso do De Veritate. Como já evidenciamos acima, essa obra condensa os resultados das lições proferidas pelo teólogo dominicano na Universidade de Paris, para os alunos da Faculdade de Teologia, futuros doutores em Teologia, que estavam em vias de se tornarem educadores - seja nas Universidades espalhadas pela Europa, seja como pregadores mendicantes ou religiosos responsáveis por alguma paróquia. Desse modo, deduz-se que a sindérese e a consciência, temas das Questões 16 e 17 do De Veritate, se constituíam como conteúdos necessários, na perspectiva do autor, para a formação daqueles educadores.

Além dos motivos que nos levaram a escolher as Questões supramencionadas como fonte para o estudo, convém tecer algumas considerações acerca do método que guia a nossa pesquisa, que é o da História Social. Desse modo, os autores que nos embasam teoricamente são os historiadores conhecidos como a primeira geração dos Annales, principalmente Marc Bloch (2001) e Lucien Febvre (1985), bem como outros estudiosos da História que acompanham, em certa medida, a perspectiva teórica desses autores, como Braudel (2014), Le Goff (1990) e Mendes (2011).

Marc Bloch (2001), em Apologia da história, ou, O ofício do historiador, evidencia dois princípios que consideramos importantes para a nossa pesquisa. Primeiro, a relação do historiador com o presente e o passado e, segundo, a necessidade de uma história-problema. Ele afirma que estudar o passado pelo passado, apenas para satisfazer uma erudição estéril, é prejudicial para os homens do presente. Assim, o historiador se relaciona com o passado a partir dos problemas vividos pela sociedade presente, e é justamente esses problemas do presente que impulsionam o historiador para o estudo do passado. Essa perspectiva conduz ao

\footnotetext{
${ }^{3}$ Não acreditamos que esse seja um critério inexorável e infalível para escolher uma determinada fonte. Concordamos com Bloch (2001) e com Mendes (2011) sobre a importância das posições assumidas pelo historiador diante do vasto material que os homens do passado nos legaram. Nos dizeres de Mendes (2011), as fontes foram produzidas como história; quem as transforma em fontes são os historiadores. Portanto, acreditamos que uma obra de Tomás de Aquino que não seja resultado direto de sua atividade docente, como a carta escrita sobre o governo do príncipe ao rei de Chipre, pode ser fonte para um historiador da educação, desde que este faça as perguntas necessárias ao documento, questões que o levem a extrair de sua fonte o que ela tem a dizer sobre a formação humana e sobre a educação dos homens de sua época.
} 
ISSN: 1984-6444 | http://dx.doi.org/10.5902/1984644430682

segundo aspecto da obra de Bloch (2001), que mencionamos acima, a necessidade de o historiador fazer perguntas aos documentos do passado, a necessidade de uma história-problema, de um posicionamento objetivo e metódico diante do passado. Isso faz com que a importância de uma pesquisa histórica seja determinada, sobretudo, pelas questões realizada pelo pesquisador.

O outro historiador da primeira geração dos Annales que nos instrui no processo de análise das fontes é Lucien Febvre (1985), principalmente no que tange ao conceito de História Social. Para ele, não há História que não seja Social - e nisso concorda com Bloch (2001). Nesse sentido, a História tem, ao fim e ao cabo, um objeto essencial: o homem. Contudo, dada a natureza política do homem, não há como pensá-lo sem considerá-lo como um ser que necessita viver em sociedade. É na sociedade que o homem se torna, efetivamente, homem, e é nela que se produz história. Por isso, priorizamos uma reflexão sobre as concepções de Tomás de Aquino sobre a formação do mestre, em relação à sociedade na qual ele viveu e produziu, de modo que suas propostas não poderiam não estar atreladas a um determinado projeto de civilização.

Além disso, consideramos relevante analisarmos nosso objeto numa perspectiva de Longa Duração, conceito desenvolvido por Fernand Braudel (2014). Segundo ele, a Longa Duração seria uma das grandes contribuições da História para o conjunto das Ciências Sociais, pois permitiria considerar o homem e a sociedade para além das causas e efeitos imediatos de suas organizações. Aliás, nós só conseguiríamos compreender o presente das instituições sociais se as olhássemos como elas se constituíram e se modificaram ao longo do tempo, no decorrer do 'Ionguíssimo' tempo, pois o tempo das instituições sociais é muito diferente do tempo que limita a vida dos indivíduos que, eventualmente, 'entram para a História'4 . Atribuir,

\footnotetext{
${ }^{4}$ Nesse aspecto, Braudel (2016) se insere numa tradição historiográfica que remota, no mínimo, aos séculos XVIII e XIX. Tocqueville (1997), por exemplo, ao estudar a Revolução Francesa em O antigo regime e a revolução, afirmou que os acontecimentos de 1789 não poderiam ser entendidos no momento em que aconteceram, fazendo referência, a nosso ver, à necessidade de investigar esses eventos numa perspectiva de Longa Duração. Outro exemplo é David Hume (2015), que se dedicou a buscar num passado bastante distante os elementos necessários para provar sua tese, segundo a qual o povo inglês 'saiu na frente' em relação a outras nações ocidentais na defesa de um governo que garantisse a liberdade dos indivíduos porque, desde a colonização pelos romanos, esse era justamente
} 
por exemplo, aos bárbaros de outrora a inteira responsabilidade pela derrocada do Império Romano é desconsiderar um conjunto de fatores, internos ao próprio Império, que o degradaram paulatinamente durante vários anos e o tornaram vulnerável.

Com a Longa Duração, Braudel (2014) não coloca na ordem do dia a existência de uma linearidade na História, de modo que o estudo do historiador se compararia ao desenrolar de um novelo de lã. A perspectiva de Longa Duração nos permite, segundo Braudel (2014), verificar rupturas e permanências em relação às instituições sociais. Tomemos o caso da Universidade, criada entre os séculos XII e XIII e que existe até hoje. Muitos historiadores que se dedicaram ao estudo dessa instituição, como Le Goff (2010), Verger (2001; 2006) e Oliveira (2012), concordam que não se pode entender sua essência sem recorrer a uma perspectiva de Longa Duração.

Nesse sentido, replicamos a pergunta que nos parece fundamental em relação ao nosso objeto: por que procuramos no século XIII, nas obras de Tomás de Aquino, lições sobre a formação do mestre, considerando que há muitas experiências mais recentes e que seriam, do ponto de vista estritamente técnico, imediatamente mais profícuas? Temos a consciência de que não podemos equiparar o mestre do século XIII com o professor do século XXI, isso seria, para dizer o mínimo, uma leitura ingênua da História. Todavia, acreditamos que alguns aspectos essenciais do mestre do século XIII se conservam, ainda hoje, na figura do professor, e a exigência de Tomás de Aquino para que o mestre seja sábio, a nosso ver, ainda tem valor, não obstante o conteúdo e a orientação ética dessa 'sabedoria'.

Dessa maneira, passaremos à análise das Questão 16 e 17 do De Veritate $^{5}$, procurando evidenciar não somente o seu conteúdo teórico, mas também o que esse debate acerca da sindérese e da consciência significava para os homens do século XIII, particularmente aqueles que teriam a incumbência de ensinar. Num primeiro momento, nos dedicaremos ao problema da sindérese e, depois, ao problema da consciência, seguindo e respeitando a abordagem didática do autor.

o seu caráter - quer dizer, sempre que um colonizador tentou suprimir certas liberdades, os ingleses procuraram reagir de alguma maneira.

${ }^{5} \mathrm{~A}$ partir desse momento, passaremos a nos referir ao De Veritate pelo título das edições em língua portuguesa, Questões disputadas sobre a verdade. 


\section{N

ISSN: 1984-6444 | http://dx.doi.org/10.5902/1984644430682

\section{A sindérese}

A Questão 16, intitulada A sindérese, está dividida em três Artigos. No primeiro, o autor procura responder se a sindérese é hábito ou potência. No segundo, a pergunta é sobre a possibilidade de a sindérese pecar, ou induzir o homem ao pecado. Por fim, no terceiro, Tomás de Aquino analisa se a sindérese pode deixar de existir em alguém.

Antes mesmo de apresentar o conteúdo da Questão e suas relações com a educação e a formação do mestre no século XIII, acreditamos ser oportuno fazer alguns apontamentos sobre o método escolástico, particularmente sobre a prática da disputatio, pois a obra de Tomás de Aquino reflete tal método ${ }^{6}$.

Nunes (1979), em História da Educação na Idade Média, apresenta de maneira sintética as práticas empregadas pelos mestres medievais, dentre as quais se destacam a lectio e a disputatio. A primeira consistia, basicamente, na leitura das autoridades, que eram as obras consideradas essenciais em cada uma das disciplinas. Essa leitura dava-se de maneira a possibilitar que mestres e estudantes apreendessem a totalidade dos textos, tanto para esclarecer os vários sentidos subjacentes às palavras e orações, como para retê-lo na memória7.

A segunda, a disputatio, foi uma criação original da ldade Média (NUNES, 1979; LIBERA, 1990; GILSON, 1995; OLIVEIRA, 2005). Consistia, fundamentalmente, num debate estruturado em 5 (cinco) 'passos': problema e hipótese, objeções, contraobjeções, solução e resposta às objeções. Assim, o conjunto desses 5 (cinco) passos

\footnotetext{
${ }^{6}$ Alguns historiadores, como Nunes (1979) e Oliveira (2005), afirmam que as obras de Tomás de Aquino representam a melhor forma do método escolástico, já que nelas pode-se observar um equilíbrio entre fé e razão, filosofia e teologia - paradigma central da Escolástica medieval.

7 O 'mercado editorial' do Ocidente medieval, por assim dizer, não permitia que os livros fossem acessíveis ao grande público. No entanto, é preciso ressaltar as inovações dos copistas e tradutores que, desde o século XII, passaram a empregar técnicas para agilizar e 'baratear' as cópias, como o sistema de peciae, um sistema de abreviações e o emprego cada vez mais frequente da minúscula gótica. Essas novas técnicas atendiam as demandas dos universitários, que passaram a conceber os livros como 'instrumentos de trabalho', mais do que como ornamentos de biblioteca (LE GOFF, 2010). Mesmo com essas inovações, o acesso aos livros era limitado e a memória era, já naquela época, um recurso indispensável a todo intelectual.
} 
forma um Artigo e um conjunto de Artigos cujos assuntos estão relacionados formam uma Questão, que é sempre temática, isto é, trata de um tema específico. Esta é a estrutura essencial do método pedagógico da Escolástica, criado e desenvolvido pelos mestres das Universidades medievais entre os séculos XII e XIII.

Havia, contudo, duas formas diferentes de Quaestiones disputatae: uma ordinária, que acontecia normalmente no período da tarde, após a leitura das autoridades; e uma extraordinária, chamada de quolibet, que acontecia geralmente em datas comemorativas, como a páscoa. As Quaestiones ordinárias versavam sempre sobre um tema pré-definido pelo mestre, tendo em vista os programas dos cursos correspondentes - Artes, Medicina, Direito ou Teologia -, e somente o mestre e os alunos regulares podiam participar. Já as Quaestiones de quolibet eram livres, podendo abarcar qualquer tema, e abertas à toda comunidade universitária, de modo que todos podiam participar ativamente. Essas últimas, mais complexas e imprevisíveis, ficavam à cargo dos mestres que se dispunham a debater com toda a Universidade, exigindo deles um amplo conhecimento das autoridades e uma atenção aguçada dos problemas da comunidade. Não raro, os temas dessas Quaestiones de quolibet tratavam de assuntos relevantes para a cidade ou o reino no qual a Universidade estava inserida, levando os mestres a se posicionarem diante dos conflitos políticos da época.

As Questões disputadas sobre a verdade, dentre as quais estão inseridas as Questões sobre a sindérese e a consciência, são Quaestiones disputatae ordinárias, isto é, são um conjunto de lições que Tomás de Aquino desenvolveu com os alunos do curso de Teologia, dentro do programa dessa Faculdade. Isso explica, do nosso ponto de vista, a orientação dada pelo autor às Questões, todas elas destinadas a temas teológicos e debatidas recorrendo a autoridades do campo da Teologia, como a Sagrada Escritura e Santo Agostinho. Contudo, não podemos deixar de observar que, embora essas Questões sejam lições para alunos de Teologia, Tomás de Aquino não se furta da responsabilidade de explicar os problemas a partir de autoridades da Filosofia sempre que necessário, principalmente Aristóteles. Aliás, verificamos que o 
ISSN: 1984-6444 | http://dx.doi.org/10.5902/1984644430682

autor recorre com frequência ao 'Filósofo', não porque ele negligencie a Sagrada Escritura, mas porque ele é, sobretudo, um escolástico ${ }^{8}$.

Diante disso, passamos ao estudo dos três Artigos da Questão 16. Como já mencionamos acima, o primeiro Artigo refere-se à natureza da sindérese, ou seja, questiona se a sindérese é uma potência ou um hábito. Todavia, antes mesmo de esclarecer o modo como concebe a sindérese, Tomás de Aquino chama a atenção para as diversas formas de entende-la em sua época. Ele se compromete, então, a investigar esses vários modos de concebe-la para verificar qual deles é verdadeiro, o que indica a importância do debate sobre a sindérese no século XIII.

Depois de apresentar essas diferentes maneiras de se entender a sindérese, o teólogo dominicano apresenta a sua concepção pessoal, a qual passa pela consideração do que seja necessário para que haja o conhecimento especulativo e o prático. Ele afirma que da mesma maneira como o conhecimento especulativo necessita de princípios certos e estáveis, a partir dos quais pode gradualmente chegar à verdade, o conhecimento prático também precisa de princípios dessa natureza, que possam servir de fundamento para a operação do agente. Além disso, esses princípios devem ser habituais, para que possam ser 'acessados' facilmente ${ }^{9}$.

Nesse sentido, Tomás de Aquino argumenta que existe na alma humana um hábito natural tanto para o conhecimento dos princípios das ciências especulativas, como para o conhecimento dos primeiros princípios operativos, "[...] que são os princípios universais do direito natural, hábito que corresponde à sindérese" (TOMÁS

\footnotetext{
${ }^{8} \mathrm{Na}$ introdução da Suma Contra os Gentios, Tomás de Aquino trata do ofício do sábio, afirmando que caberia a ele, o sábio, procurar a verdade, não simplesmente repetir o que outros disseram. Essa é, a nosso ver, uma síntese da essência do intelectual escolástico, que deve procurar a verdade onde quer que ela esteja - na Sagrada Escritura, mas também em Santo Agostinho, em Boécio, em Aristóteles, em Platão, em Maimônides, em Damasceno etc.

${ }^{9}$ Convém esclarecer que Tomás de Aquino busca em Aristóteles o conceito de hábito. Assim, um hábito é um ato ou ação que o sujeito sabe realizar, algo com que tem familiaridade. Uma pessoa que tem, por exemplo, o hábito da leitura não fica o tempo todo lendo, mas quando se compromete a ler, tem todas as condições para fazê-lo com eficácia e sem maiores dificuldades. Nessa perspectiva, os princípios que a sindérese contém, por assim dizer, devem ser habituais no sentido de estarem sempre disponíveis e dispostos, a fim de servirem para o julgamento das ações presentes e futuras.
} 
ISSN: 1984-6444 | http://dx.doi.org/10.5902/1984644430682

DE AQUINO, $D V$, q. 16, a. 1, sol. $)^{10}$. Assim, esse hábito que corresponde à sindérese faz parte da razão, isto é, está submetido à potência intelectiva.

Tomás de Aquino aborda essa relação entre intelecto e sindérese na resposta às objeções desse primeiro Artigo. Na resposta dada à décima quarta objeção, o autor afirma que: "Respondo dizendo que o ato do conhecimento não é pressuposto para a potência ou o hábito da sindérese, mas só para o seu ato. Por isso, não se exclui que o hábito da sindérese seja inato" (TOMÁS DE AQUINO, DV, q. 16, a. 1, resp. 14).

Diante disso, observamos que, para Tomás de Aquino, a sindérese depende do intelecto em seu ato, não em sua existência na alma. Isso significa que é provável que a sindérese seja inata, mas é improvável que ela se manifeste sem que o intelecto se atualize. Verificamos, então, que aprendizagem e reflexão, efeitos do intelecto em ato, e agir de acordo com o direito natural, efeito do hábito da sindérese, estão interligados de acordo com a perspectiva tomasiana.

Essas primeiras conclusões conduzem ao tema do segundo Artigo da Questão 16, que trata da possibilidade de a sindérese conduzir ao pecado. As objeções apresentadas ao tema desse segundo Artigo se concentram no fato de a sindérese estar na razão para afirmar que sim, a sindérese pode pecar. Ou seja, uma vez que a razão lida com contrários, notadamente com a virtude e com o vício, parece ser evidente que a sindérese, hábito dos primeiros princípios operativos, pode conduzir o homem ao pecado.

No entanto, esse posicionamento contém desdobramentos relevantes para a cristandade ocidental do século XIII. Considerando que a sindérese é inata, fazendo parte do composto humano, podemos afirmar que ela é resultado direto do ato da criação. A sindérese não faz parte da razão por alguma ação do homem, mas sim pela ação de Deus ao cria-lo com o hábito sindérese. Nesse sentido, afirmar que a

\footnotetext{
10 Todas as referências às Questões disputadas sobre a verdade serão feitas dessa maneira. Devemos le-la da seguinte maneira: Tomás de Aquino, De Veritate, Questão 16. Artigo 1, solução. Quando citarmos alguma outra parte do artigo, como as objeções ou as respostas às objeções, o termo 'sol.' será substituído por outro que designa a parte exata que estará sendo citada. Para as objeções, utilizaremos 'obj.' mais o número correspondente da objeção; para as respostas às objeções, utilizaremos 'resp.' mais o número correspondente da objeção respondida. A citação a outras obras do teólogo dominicano seguirão a mesma lógica, isto é, nome do autor, obra citada, parte da obra que estamos citando, seja ela Questão, Livro, Capítulo etc.
} 
sindérese pode conduzir o homem ao pecado equivale a dizer que Deus predispõe o homem ao pecado de propósito, dado que tudo que é feito por Deus é feito por sua vontade (cf. TOMÁS DE AQUINO, SCG, L. II). Contudo, fazer tal afirmação contraria a verdade da fé segundo a qual Deus criou todas as coisas pelo bem e para o bem, além de indicar que em Deus pode haver pecado.

Tomás de Aquino resolve esses problemas considerando, primeiro, a perfeição da natureza criada. Com efeito, os princípios que permitem a operação da natureza, segundo ele, são permanentes, imutáveis e conservam sua retidão. Desse modo, todo conhecimento especulativo deriva de princípios universais e infalíveis, de modo que pode incorrer em erro não por causa dos princípios, mas sim pelo que pode acontecer no decorrer do processo de especulação. O mesmo acontece com o conhecimento prático e a ação do homem, ou seja, há princípios universais e infalíveis na forma de hábitos que nos indicam um determinado caminho a seguir. Destarte, verificamos que na perspectiva de Tomás de Aquino não existe pecado na sindérese porque não é do seu ofício concordar com o mal, nem sob a razão de bem. Assim, a sindérese se constitui como uma espécie de fortaleza moral do homem, que ele pode ou não alimentar dependendo das escolhas que faz cotidianamente.

Com o objetivo de concluir a Questão 16, Tomás de Aquino passa ao terceiro Artigo, no qual indaga se a sindérese pode ser extinta em alguém. Ele inicia a sua conclusão distinguindo duas formas de se entender a extinção da sindérese. Em primeiro lugar, pode-se entender a extinção da sindérese pela extinção da 'luz habitual', isto é, pelo desaparecimento da sindérese da alma humana. Isso, segundo o autor, é impossível, uma vez que a sindérese é um dos elementos que caracteriza a alma intelectual, de modo que sem a sindérese ela deixaria de ser 'alma intelectual'.

O segundo modo de se entender a extinção da sindérese é de acordo com o ato, o que pode acontecer de duas maneiras: quando o ato da sindérese é completamente impedido e quando a ação humana se encaminha para o contrário em relação ao hábito da sindérese. No primeiro caso, a sindérese deixa de existir na medida em que o sujeito não usufrui do livre-arbítrio e da razão. No segundo caso, o juízo da sindérese não desaparece, mas ela deixa de existir na operação particular na medida em que se peca na eleição. 
Nessa perspectiva, Tomás de Aquino conclui que é impossível que a sindérese deixe de existir em alguém de modo absoluto. Portanto, mesmo que cometamos erros ao longo da vida, continuamos munidos do hábito da sindérese, pelo qual podemos, em qualquer momento, passar a fazer escolhas positivas e praticar ações genuinamente boas. Esse posicionamento é significativo para a época de Tomás de Aquino. Com efeito, o século XIII foi o momento em que o pecado e o pecador começavam a ser vistos de maneira diferente, com a implantação da confissão auricular por parte dos frades mendicantes (LE GOFF, 2008). Além disso, foi o tempo em que as cidades se consolidaram como os principais espaços de sociabilidade e de produção da vida (OLIVEIRA, 2012). Enfim, foi um período de desenvolvimento da civilização do Ocidente medieval, tanto geográfica como política e economicamente (FEBVRE, 2004; LE GOFF, 2005). Portanto, a reflexão sobre a sindérese de Tomás de Aquino se insere nesse contexto, de modo que não se constitui somente como um problema filosófico e teológico, mas também político, na medida em que levanta questionamentos sobre o modo como nos organizamos em sociedade.

\section{A consciência}

A partir de agora, passamos a tratar do problema da consciência. Ressaltamos que, na perspectiva de Tomás de Aquino, o hábito da sindérese e a consciência são elementos que se completam, como se verá adiante. Entendemos que estudar a sindérese como um dos fundamentos para a formação do mestre no século XIII, a partir da obra do teólogo dominicano, conduz à análise do debate sobre a consciência, pois assim, respeitamos a perspectiva de totalidade com a qual o autor concebe a natureza do homem. Com efeito, sindérese e consciência são elementos que compõem a totalidade da natureza humana, definida a partir do intelecto. Dessa maneira, a compreensão da sindérese e da consciência passa pela reflexão acerca 
ISSN: 1984-6444 | http://dx.doi.org/10.5902/1984644430682

do intelecto, a partir da qual é possível, segundo o autor, entender as características da alma humana em sua complexidade ${ }^{11}$.

O problema da consciência é analisado na Questão 17 das Questões disputadas sobre a verdade, aparecendo logo após a discussão sobre a sindérese. Verificamos que a reflexão acerca da consciência aponta para a necessidade de o autor explicar a seus alunos o fator determinante para a existência, no homem, de uma vontade consciente, isto é, de uma potência apetitiva que se atualiza mediante o conhecimento e o hábito. Essa décima sétima Questão está dividida em cinco artigos: no primeiro, questiona-se se a consciência é potência, hábito ou ato; no segundo, se a consciência pode errar; no terceiro, se a consciência obriga; no quarto, se a consciência errônea obriga; e, no quinto, se a consciência errônea em temas indiferentes obriga mais ou menos do que o preceito do superior.

O primeiro Artigo da Questão 17 apresenta características distintas em relação à maioria das Questões tomasianas. Observamos que o autor traz quatro conjuntos diferentes de objeções. Assim, apresentam-se objeções que pretendem provar que a consciência é uma potência, outras que afirmam que a consciência não é um hábito, um terceiro conjunto de objeções que consideram a consciência uma espécie de hábito e, por fim, aquelas que acreditam que a consciência é um ato - totalizando 24 objeções, um número incomum para as obras do teólogo dominicano. Acreditamos que essa variedade de objeções deve-se à importância da pergunta feita nesse primeiro Artigo, ou seja, o que exatamente é a consciência, uma potência, um hábito ou um ato? Por isso, o autor verifica que existiam, em sua época, diferentes respostas a esse questionamento, o que evidencia a necessidade de discuti-lo.

Na solução da Questão, Tomás de Aquino admite haver certa confusão em torno do termo 'consciência', confusão que pretende solucionar recorrendo principalmente à Bíblia e à Aristóteles, mas também à etimologia da palavra. Esse primeiro Artigo é indispensável para a compreensão do conceito tomasiano de

\footnotetext{
11 O modo totalizante pelo qual Tomás de Aquino concebe o homem, partindo do conceito de intelecto, é uma discussão que nós estamos fazendo em nossa tese de doutorado, cujo tema é a forma como o teólogo dominicano concebe a formação do mestre. Nossa tese é de que, para Tomás de Aquino, a 'sabedoria' do mestre do século XIII está atrelada a um estudo profundo do intelecto como elemento determinante da natureza humana.
} 
ISSN: 1984-6444 | http://dx.doi.org/10.5902/1984644430682

consciência, além de ser a chave para a análise dos Artigos seguintes, que colocam em evidência a relação entre consciência e ato moral. Desse modo, já nesse primeiro artigo podemos perceber a relação necessária entre consciência e educação.

\begin{abstract}
Com efeito, o nome consciência significa a aplicação da ciência a algo. Por isso, consciência significa 'com ciência', como um simultâneo saber. Qualquer ciência pode ser aplicada a algo, motivo pelo qual a consciência não pode nomear algum hábito especial ou alguma potência, mas designa o próprio ato, que é a aplicação de qualquer hábito ou de qualquer conhecimento a algum ato particular. (TOMÁS DE AQUINO, DV, q. 17, a. 1, sol.).
\end{abstract}

Verificamos que, diante da diversidade de opiniões acerca da consciência, Tomás de Aquino recorre à etimologia para afirmar que consciência significa, propriamente, aplicar a ciência e o hábito para se fazer alguma coisa. Um químico, por exemplo, descobre um novo elemento na medida em que mobiliza o que sabe para chegar a algum resultado, fazendo com que sua descoberta se dê de maneira consciente, isto é, mediante a aplicação de certos saberes e de certos hábitos.

Contudo, o autor explica que há duas maneiras de se considerar a consciência como aplicação da ciência a ato. Em primeiro lugar, verifica-se se 0 ato existe ou existiu, no sentido de reconhecer se temos ou não conhecimento de determinado ato. Em segundo lugar, averígua-se se o ato é reto ou não é reto, isto é, procura-se reconhecer a moralidade da ação tendo em vista um conjunto de princípios e valores mediante os quais se pode julgá-la. Nesse sentido, essa segunda forma de conceber a consciência se desdobra em duas 'vias': analisa-se, por um lado, se a ação deve ou não deve ser realizada e, por outro, se uma determinada ação já realizada foi correta ou não foi correta.

Essas duas vias referentes à aplicação da ciência e do hábito para julgar uma ação correspondem, segundo Tomás de Aquino, às duas vias da parte especulativa do homem, pelas quais ele é capaz de investigar e de julgar as coisas. Pela investigação, chega-se a uma decisão sobre se a ação deve ou não deve ser realizada, e pelo julgamento emite-se uma certa análise moral das ações já realizadas. Nessa perspectiva, quando dizemos que temos 'consciência' estamos, primeiro, reconhecendo o conhecimento ou não de determinado ato; segundo, reconhecendo a retidão ou a não retidão de determinado ato, o que pode ser feito tanto com ações 
presentes e futuras, como com ações passadas. Portanto, o nível de consciência, de acordo com o autor, está intimamente relacionado ao nível de ciência, pois quanto mais e melhor for o saber, mais abrangente as capacidades de investigar e julgar, melhor é o ato de consciência.

Além disso, é no processo de investigação e de julgamento sobre a retidão das ações que sindérese e consciência se encontram. Quando investigamos e julgamos as ações, precisamos aplicar, segundo Tomás de Aquino os hábitos da razão operativa

[...] ou seja, o hábito da sindérese e o hábito da sabedoria, pelos quais se aperfeiçoa a razão inferior, ou se aplicam simultaneamente todos ou um deles de cada vez. Com efeito, mediante estes hábitos, examinamos o que fizemos e somos aconselhados acerca do que devemos fazer. Contudo, o exame não é só do ato feito, mas também do que há de ser feito, enquanto o conselho é apenas do que há de ser feito. (TOMÁS DE AQUINO, DV, q. 17, a. 1, sol.).

Observamos que, segundo o teólogo dominicano, a consciência entendida como exame das ações a serem realizadas e das ações já realizadas implica duas espécies de hábitos, o da sindérese e o da sabedoria. Essa afirmação é fundamental para entendermos a relação entre o desenvolvimento da consciência e a educação, pois os hábitos da sindérese e da sabedoria são, como afirma o próprio autor fundamentado em Aristóteles, constituídos ao longo da vida, por meio das escolhas que fazemos e do que aprendemos. Por mais que a sindérese seja considerada pelo autor um hábito natural, infundido no homem por Deus, o fato de ela ser um 'hábito' a torna um elemento que precisa ser alimentado, cultivado. E cultivá-lo é algo que se ensina e se aprende.

Verificamos, ainda no primeiro Artigo, a interlocução da obra com questões da época em que o teólogo dominicano viveu. Na resposta dada à terceira objeção, que visava defender a hipótese de que a consciência é uma potência, o autor refuta essa hipótese e justifica e admite a possibilidade da purificação da consciência manchada pelo pecado. Essa purificação dar-se-ia pelo reconhecimento da não retidão de determinado ato, segundo os dogmas da religião cristã, por meio do 'exame de consciência'. Isso impunha, por seu turno, a necessidade de os ministros da Igreja reverem suas práticas. 
ISSN: 1984-6444 | http://dx.doi.org/10.5902/1984644430682

Com efeito, foi no século XIII e com as Ordens Mendicantes que a Igreja inaugurou a prática da confissão auricular, modificando o modo como tratava os fiéis em pecado e com necessidade de redenção (cf. LE GOFF, 2008). Acreditamos que a possibilidade de perdão dos pecados por meio dessa nova forma de confissão se torna viável, dentre outras coisas, pelo reexame das concepções acerca do funcionamento do intelecto humano. Entendemos que o fato de o homem poder, depois de ter pecado, constatar a impureza de suas ações por meio da consciência é uma das bases para essa reforma de iniciativa dos mendicantes.

Para finalizar nosso estudo da Questão 17, analisaremos, a seguir, o Artigo 2, no qual o autor questiona se a consciência pode errar. Enfatizaremos esse Artigo em detrimento dos demais porque ele está mais proximamente relacionado aos nossos objetivos neste texto, que são o de refletir sobre os conceitos tomasianos de sindérese e de consciência e suas relações com a formação humana na perspectiva da História da Educação.

Nesse sentido, o Artigo 2 da Questão 17 apresenta duas considerações relevantes, uma principal, que corresponde ao núcleo fundamental do Artigo, e outra que é um esclarecimento importante no contexto do nosso trabalho. Primeiro, o autor argumenta que a consciência pode errar, mas que precisamos localizar a origem do erro:

Respondo dizendo, como já foi dito, que a consciência é a aplicação da ciência a algum ato especial. De fato, em sua aplicação pode ocorrer erro de dois modos. Um modo, que o princípio que se aplica seja falso. Outro modo, que também não se faça corretamente a aplicação. Como também no silogismo ocorre dupla falha: que se usem premissas falsas ou que não se argumente corretamente. Ora, este uso de premissas falsas pode ocorrer por uma parte, mas não ocorrer por outra parte. Com efeito, foi dito acima que se aplica pela consciência o conhecimento da sindérese, da razão superior e inferior, ao ato particular que se deve examinar. (TOMÁS DE AQUINO, DV, q. 17 , a. 2, sol.).

Observamos que as reflexões do teólogo dominicano sobre os erros da consciência apontam para duas direções: a consciência erra quando o princípio é equivocado e quando o princípio, mesmo correto, é aplicado de maneira errada. Considerando que a consciência se aprimora, por assim dizer, por meio da sindérese, da razão superior e da razão inferior, Tomás de Aquino é instado a identificar e apontar a origem do erro de consciência. 
Por isso, o autor explica que o erro da consciência não pode ser causado pelo saber oriundo da sindérese, pois, como já verificamos na análise da Questão 16, os primeiros princípios operativos do homem, que compõem o hábito da sindérese, são desprovidos de qualquer falha. Portanto, ele atribui à razão superior e à razão inferior as responsabilidades pelo erro na consciência, isto é, nossa consciência está sujeita ao erro na medida em que ela depende, sobretudo, da atualização das potências intelectiva e apetitiva do homem. Nossa consciência pode trilhar qualquer caminho mediante as coisas que aprendemos, pensamos e escolhemos no decorrer da existência. A sindérese estaria em nós, como um dado da natureza, mas traze-la ao nível da consciência é algo que estaria atrelado à experiência particular de cada um.

Esse debate se insere, do nosso ponto de vista, no contexto de retomada da Península Ibérica por parte da Cristandade Ocidental. Até meados do século XI, a região que hoje compreende Portugal e Espanha foi predominantemente muçulmana. Do ano mil até o final da Idade Média, a Civilização Cristã procurou expandir seus domínios à oeste para além das fronteiras da França, expansão que se dava pela iniciativa militar, inspirada pelo 'espírito de cruzada', mas também pela iniciativa teórica, intelectual (RUSSELL, 2015).

O avanço pela via das ideias acontecia, principalmente, pelo trabalho de convencimento encabeçado pelas Ordens Mendicantes. A produção da Suma Contra os Gentios por Tomás de Aquino, na segunda metade do século XIII, é exemplar desse processo: essa obra foi escrita à pedido de outro frade dominicano, Raimundo de Penaforte, visando a instrução dos frades cujo trabalho era, exatamente, a conversão dos povos ibéricos. Além da Suma Contra os Gentios, podemos encontrar em outros textos tomasianos evidências desse combate de ideias, e o posicionamento do autor sobre o erro da consciência nas Questões disputadas sobre a verdade é um exemplo disso. Como o frade dominicano poderia convencer um muçulmano a mudar seu posicionamento religioso e político, se pensa que a consciência jamais erra? Além disso, como ele explicaria a esse muçulmano que a consciência pode errar, mas que a consciência cristã é mais correta que a consciência muçulmana? Nossa intenção não é emitir juízos de valor acerca de uma ou outra religião, mas para os homens do 


\section{Us: entinab̧a}

ISSN: 1984-6444 | http://dx.doi.org/10.5902/1984644430682

século XIII essas questões eram relevantes, não somente na perspectiva doutrinária, mas também política.

Desse modo, observamos que esse segundo Artigo da Questão 17 também evidencia o compromisso de Tomás de Aquino com um projeto de civilização, do da Cristandade Ocidental. Entretanto, como já adiantamos, há outro aspecto desse Artigo que gostaríamos de destacar, que é a distinção entre sabedoria e conhecimento teórico, acadêmico. Na resposta à segunda objeção, o autor esclarece que quando se refere ao 'conhecimento' para tratar da consciência, não faz alusão ao 'conhecimento estrito', aquele que se dedica a conhecer a 'verdade', o conhecimento das teorias filosóficas e científicas. Ao contrário, a referência é a uma concepção abrangente de conhecimento: "[...] ciência considerada no sentido amplo, que tem em conta qualquer conhecimento, na medida em que tudo que conhecemos, no uso comum da linguagem, dizemos saber" (TOMÁS DE AQUINO, DV, q. 17, a. 2, resp. 2.).

Essas reflexões são importantes porque, a nosso ver, apontam para uma diferenciação que é negligenciada até nos dias atuais. Observamos na sociedade uma dupla percepção do conhecimento: por um lado, há a apologia da ignorância daqueles que afirmam que a escola é inútil por natureza, pois só é capaz de formar burocratas alienados e incapaz de ensinar a ser 'gente'; e, por outro lado, há a apologia da intelectualidade daqueles que acreditam que o acumulo de experiências acadêmicas conduz, naturalmente, à sabedoria. A leitura dos textos tomasianos permite concluir que essas duas posições estão equivocadas. A sabedoria, que deve, segundo Tomás de Aquino, compor a consciência em conjunto com a sindérese, designa todo o saber possível de ser alcançado, bem como a interface desse saber com a experiência cotidiana. Negligenciar o conhecimento formal, acadêmico, superestimando o senso comum, ou exaltar as ciências e a filosofia, menosprezando o senso comum como 'menor' na hierarquia dos saberes são duas maneiras distintas de negar a sabedoria no sentido tomasiano do termo. 
ISSN: 1984-6444 | http://dx.doi.org/10.5902/1984644430682

\section{Considerações finais}

Assim, consideramos relevante trazer essas análises de Tomás de Aquino sobre a sindérese e a consciência para o campo da História da Educação, pois entendemos que elas se inserem num conjunto de saberes voltados para a formação do mestre que pode ser entendido numa perspectiva de Longa Duração. Não temos a pretensão de estabelecer uma compreensão definitiva e universal a respeito das concepções tomasianas acerca da formação do mestre, nem tampouco demonstrar que suas ideias são atemporais e servem para nós, hoje, da mesma maneira como serviam aos homens do século XIII. Nós objetivamos, apenas, defender a tese de que ao admitir nada menos do que a condição de sábio para tornar-se mestre, Tomás de Aquino estabelece um conjunto de conhecimentos teórico-prático necessário para se chegar a sabedoria, isto é, para se tornar, efetivamente, um mestre, um educador. Nesse sentido, compreendemos que os debates acerca da sindérese e da consciência nas Questões Disputadas Sobre a Verdade compõem esse amplo e complexo conjunto de conhecimento, não somente porque eram caros à teologia cristã, mas também porque eram caros à cristandade.

Nesse sentido, Tomás de Aquino reafirma o compromisso da Universidade medieval com a formação de quadros qualificados tanto para o trabalho específico no campo da Teologia, como para a ação política de fortalecimento das instituições que davam à cristandade o substrato para desenvolvimento dos indivíduos e das relações sociais. Essa talvez seja a principal lição que podemos aprender com o estudo de suas obras, ou seja, em que medida nós, professores, nos comprometemos com a civilização no dia-a-dia das escolas, faculdades e universidades? Como separamos paixões políticas e opiniões pessoais do conteúdo que precisamos ensinar e que os alunos precisam aprender? Evidentemente, não podemos esquecer o que nós somos, pensamos e sentimos de nossa ação pedagógica, mas precisamos manter o compromisso de estudar sempre - e de verdade -, de conceber a prática docente sempre a partir de um projeto de sociedade - que deve ser claro e explícito - e pensar como universitários, com o espírito de universitas que foi e continua sendo a alma da Universidade. 


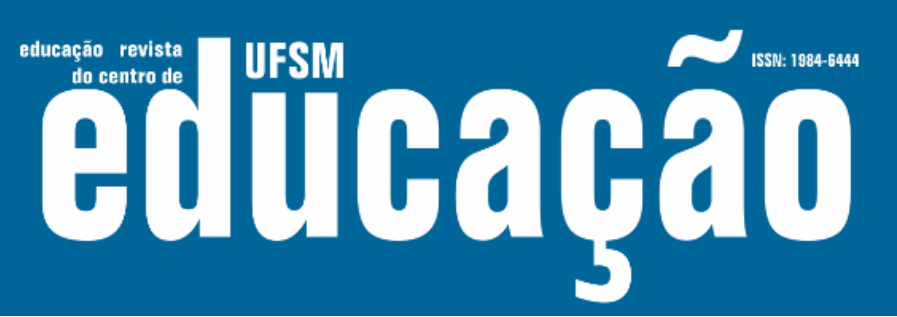

ISSN: 1984-6444 | http://dx.doi.org/10.5902/1984644430682

\section{Referências}

BLOCH, Marc L. B. Apologia da história, ou, 0 ofício do historiador. Rio de Janeiro: Jorge Zahar Ed., 2001.

BRAUDEL, Fernand. Escritos sobre a história. São Paulo: Perspectiva, 2014.

FEBVRE, Lucien. Combates pela história. Lisboa: Editorial Presença, 1985.

FEBVRE, Lucien. A Europa: gênese de uma civilização. Bauru: EDUSC, 2004.

GILSON, Étienne. A filosofia na Idade Média. São Paulo: Martins Fontes, 1995.

HUME, David. História da Inglaterra: da invasão de Júlio César à Revolução de 1688. São Paulo: Editora Unesp, 2015.

LAUAND, Jean. Introdução. In: TOMÁS DE AQUINO. Sobre o ensino (De Magistro), os sete pecados capitais. São Paulo: Martins Fontes, 2004.

LE GOFF, Jaques. História e memória. Campinas: Editora da UNICAMP, 1990.

LE GOFF, Jaques. A civilização do Ocidente Medieval. Bauru: EDUSC, 2005.

LE GOFF, Jaques. Uma Ionga Idade Média. Rio de Janeiro: Civilização Brasileira, 2008.

LE GOFF, Jaques. Os Intelectuais na Idade Média. Rio de Janeiro: José Olympio, 2010.

LIBERA, Alain. A filosofia medieval. Rio de Janeiro: Jorge Zahar Editor, 1990.

MENDES, Claudinei M. M. A importância da pesquisa de fontes para os estudos históricos. Acta Scientiarum. Education, Maringá, v. 33, n. 2, p. 205-209, jul./dez. $2011 . \quad$ Disponível em: http://periodicos.uem.br/ojs/index.php/ActaSciEduc/article/view/14174. Acesso em 15 mar. 2017.

NUNES, Ruy A. da C. História da Educação na Idade Média. São Paulo: EPU, 1979.

OLIVEIRA, Terezinha. Escolástica. São Paulo: Mandruvá, 2005.

OLIVEIRA, Terezinha. Ensino e debate na universidade parisiense do século XIII: Tomás de Aquino e Boaventura de Bagnoregio: textos. Maringá: EDUEM, 2012. 


\section{OF

ISSN: 1984-6444 | http://dx.doi.org/10.5902/1984644430682

RUSSELL, Bertrand. História da filosofia ocidental. Rio de Janeiro: Nova Fronteira, 2015. (Livro 2: a filosofia católica).

TOCQUEVILLE, Alexis. de. O antigo regime e a revolução. Brasília: Editora da Universidade de Brasília, 1997.

TOMÁS DE AQUINO. Suma Contra os Gentios. São Paulo: Edições Loyola, 2015. 4 $\mathrm{v}$.

TOMÁS DE AQUINO. A sindérese e a consciência: questões disputadas sobre a Verdade, Questões 16 e 17. Campinas: Ecclesiae, 2015.

TORRELL, Jean-Pierre. Iniciação à Santo Tomás de Aquino. São Paulo: Loyola, 2004.

VERGER, Jaques. Cultura, ensino e sociedade no Ocidente nos séculos XII e XIII. Bauru: EDUSC, 2001.

VERGER, Jaques. Universidade. In: LE GOFF, J.; SCHMITT, J.-C. (Orgs.). Dicionário Temático do Ocidente Medieval. Bauru: Edusc, 2006.

\section{Correspondência}

Rafael Henrique Santin- Professor doutor da Educação Básica Técnica e Tecnológica do Instituto Federal do Paraná - Campus Palmas.

Terezinha Oliveira- Professora doutora Titular da Universidade Estadual de Maringá junto ao Departamento de Fundamentos da Educação e ao Programa de PósGraduação em Educação.

Instituto Federal do Paraná - Campus Palmas. Av. Bento Munhoz da Rocha Neto s/no - PRT-280, Trevo da Codapar, Palmas, 85555-000. Paraná, Brasil.

E-mail: rafael.h.santin@gmail.com-teleoliv@gmail.com

ORCID iD: http://orcid.org/0000-0002-8520-4592- http://orcid.org/0000-0001-53491059

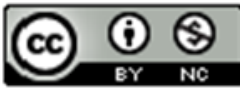

This work is licensed under a Creative Commons Attribution-NonCommercial 4.0 International (CC BY-NC 4.0) 